\title{
Multimodal Engagement through a Transmedia Storytelling Project for Undergraduate Students
}

\author{
Melissa Shamini Perry \\ mel@ukm.edu.my \\ Universiti Kebangsaan Malaysia
}

\begin{abstract}
Transmedia storytelling has great potential in the field of education and research on its applications and benefits in teaching and learning is growing. This paper explores the use of transmedia storytelling as a multimodal pedagogical tool for tertiary students. This paper explicates the design and application of a transmedia storytelling project in increasing multimodal engagement for undergraduate students from various faculties. A case study of a transmedia storytelling campaign conceptualised and produced by undergraduate students from a Malaysian public university was analysed for evidence of multimodal engagement. Students' project output including campaign pitches, campaign designs and artefacts such as scripts, storyboards, posters, photos and videos submitted via digital formats were collated and analysed using a multimodal framework. Post-assessment reflections submitted by students were also analysed. The findings of the case study revealed that the conceptualisation and production of a transmedia storytelling campaign consisting of a short film, book and social media page enabled students to engage with multiple modalities and develop various skills and competencies. Analysis of campaign artefacts and student reflections found that the use of this novel pedagogy enabled students to engage with visual and spatial, linguistic, audio, gestural and technical digital modes of meaning as well as develop literary competencies and creative thinking skills through this project. This paper paves the way for further exploration of the use of transmedia storytelling as a multimodal pedagogical tool to develop various literacies, educational competencies as well as $21^{\text {st }}$ century skills amongst tertiary students.
\end{abstract}

Keywords: multimodality; transmedia; storytelling; pedagogy; higher education

\section{INTRODUCTION}

Teaching and learning practices across the globe have begun to shift from using primarily language-based pedagogies to multimodal ones in order to increase learner engagement and reflect $21^{\text {st }}$ century technological and communication trends. As observed by Nouri (2018), students today are mobile and flexible learners who use the affordances of different technologies to construct knowledge and meanings through different semiotic modes. These students make up a generation referred to as the digital natives, who were born into the digital era and are surrounded and immersed in digital technologies. For digital natives, technology is a ubiquitous and indispensable essential element in their daily lives and they have new ways of thinking about and applying technology and media (Dingli \& Seychell 2015). They use media that provide meaning through not only language, but also other modes such as visual, aural, gestural and musical in their everyday living and learning experiences (Toohey et al., 2015).

Development in technology and availability and access to a variety of digital resources provide students the opportunity to enhance and support their learning experiences to suit their individual needs and learning styles. Mobile learning is a key example that provides students with the interactive aspect and flexibility to learn at their own pace and time (Wong et al., 2012). However, many educational institutions have yet to fully tap into and develop the 
potential and skills that these learners possess by providing them with learning experiences that offer multimodal engagement which allows learners to experience meaning making through various modes of meaning. The emphasis still firmly remains on reading and writing texts in $21^{\text {st }}$ century teaching and learning contexts although other skills and mediums are slowly being recognized (Suraini et al., 2018). Efforts to increase students' engagement with multimodal texts have been limited even in tertiary education environments as multimodal assignments can challenge traditional notions of what counts as academic work (Bowen, 2017).

Fortunately, the situation is improving as institutions and educators begin to realise the importance of embracing change in order to effectively educate and communicate with the digital savvy learners of today. Researchers and practitioners have begun investigating how to move education beyond print-based practices to become more multimodal and digital after recognizing "that access to combinations of modes for meaning making have shifted with the availability of digital tools like the Internet and personal computing, so that, for example, even children can produce multimodal text that integrates images, hyperlinks, video, audio, and so on" (Toohey et al. 2015, p.464). However, having access and exposure to multiple modes of meaning and media does not necessarily mean these students have the ability to view and use the multimodal representations critically and skilfully (Lim \& Tan, 2018; Zammit, 2007). Appropriate teaching and learning practices can provide multimodal engagement for students that help them expand their repertoire of making sense of complex multimodal texts in a skilful and critical manner (Serafini, 2014). It is therefore vital that educators have the knowledge of and access to suitable theoretical, curricular and pedagogical frameworks that would enable them to provide an engaging multimodal learning experience for their students (Lim \& Tan, 2018; Serafini, 2014).

This paper explores the applications of transmedia storytelling as a multimodal pedagogical tool in higher education contexts. This paper presents a case study of the use of transmedia storytelling as a formative assessment for a Literature and the Media course to increase multimodal engagement in undergraduate students from a public university in Malaysia. It will focus on the students' engagement with multimodality, i.e., their interaction with and use of visual and spatial, linguistic, audio, gestural and technical and digital modes of meaning in the conceptualization and production of a transmedia storytelling campaign. The following sections will discuss transmedia storytelling and its applications in education.

\section{TRANSMEDIA STORYTELLING}

Transmedia storytelling (henceforth referred to as TS), is a form of storytelling that unfolds a narrative across multiple media channels and seeks to provide audiences, especially the digital native generation with the engagement and interaction they seek. TS is possible due to the technological advancements of the $21^{\text {st }}$ century that have elevated the art of storytelling and allowed for stories to be created and disseminated through multiple modes of meaning. TS therefore, embodies $21^{\text {st }}$ century multimodal communication and provides multimodal engagement for both the producers and users. In a multimodal text, meaning is created when multiple modes of meaning are "simultaneously present and operating within a communicative context" (Kress et al. 2001, p.43). The same applies to multiplatform storytelling such as TS, where meaning is created through the combination of all the modes and platforms operating within one core narrative or storyworld.

In TS, a narrative of a story is dispersed in a seamless manner through different platforms (Kalogeras, 2014). It is important to note that TS is not a mere retelling of a story in a different medium or platform. The film adaptation of a book which presents the narrative of the book in motion picture format is not TS. In TS, each platform contains different elements of a narrative (such as new plots, characters and points of view) and the entire narrative unfolds 
across multiple media platforms where it can continue to grow and evolve. A key characteristic of a transmedia narrative is that any of the platforms can act as an entry point into the storyworld by the reader or audience. Other characteristics include the potential of the storyworld for seriality, multiplicity and to provide immersive experiences for the audience (Pratten, 2015). In recent years, the applications of TS have gained recognition in the field of education as a versatile pedagogical tool to develop multiple skills and competencies in diverse fields and disciplines of study. The following section discusses applications of TS in education.

\section{TRANSMEDIA STORYTELLING IN EDUCATION}

The core elements of TS which are storytelling and multimodality, appeal to both teachers and students of all levels. According to Kalogeras (2014), TS has led to the evolvement of narratives and learning through stories, which are central to new pedagogical modes. The application of TS as a multimodal pedagogical tool or transmedia learning is gaining recognition and research is being done on its application and benefits in various education contexts (Bidarra \& Rodrigues, 2018; Fleming, 2013; Kalogeras, 2014). According to Fleming (2013), "transmedia learning is the application of storytelling techniques combined with the use of multiple platforms to create an immersive learning landscape which enables multifarious entry and exit points for learning and teaching" (p. 371).TS's multiplatform feature enables the combination of both traditional and digital learning tools which makes it a versatile pedagogical tool for educators to apply in diverse learning environments.

A variety of TS teaching methods and materials that include modules, e-modules, games, creative productions, projects and branding campaigns have been designed by educators and researchers in order to reap and maximize the educational benefits that TS can offer learners. TS's versatility and wide-ranging applications have allowed educators in language classrooms to use it to develop language acquisition, multiple literacies and other educational competencies in students. Rodrigues and Bidarra (2016) studied the use of transmedia projects as an educational strategy in the context of ESL- English as a Second Language learning. The study found that students used a multi-layered combination of audio-visual elements within a storyworld to shed light on various topics including culture, communication and technology use (Rodrigues \& Bidarra, 2016). Kalogeras (2014) designed a TS e-module that involves interaction with transmedia content in order to enhance multimodal and digital literacies in tertiary students.

The use of TS in teaching and learning has had many benefits and contributed to the development in various skills and competencies in students including the development of higher-order skills including critical thinking, analysis and problem-solving (Kalogeras, 2014). Gambarato and Dabagian (2016) found that transmedia strategies are learner centred and help students be motivated and develop multiple digital literacies, interpersonal communication skills and knowledge in various fields. In ESL learners, transmedia strategies facilitate the acquisition, development and improvement of ESL skills and promoted social skills such as interactions, collaboration and networking amongst learners (Rodrigues \& Bidarra, 2016). Through TS, students have a variety of media channels and an immersive learning experience that enables them to build on their existing skills and encourages collaborative problem solving (Pence, 2012). Students with differing learning styles and levels of literacies can choose the type of media and mode of meaning that they are most comfortable with to begin their learning process and then move on to other media platforms to develop their knowledge and skills.

Herr-Stephenson et al. (2013) used transmedia play which involved experimentation with and participation in a transmedia experience to help learners develop media literacy. Students who engaged in transmedia play were able to locate, organize, and reorganize information dispersed across various knowledge communities and do creative and 
collaborative reworking of media content (Herr-Stephenson et al., 2013). Sánchez-Martinez and Albaladejo-Ortega (2018), employed TS through an innovative teaching project "to improve the acquisition of transversal and disciplinary educational competencies" among university media students (p. 52). The project was found to develop creativity and boost learning motivation in students. Transmedia projects enabled students to employ various modalities and technology through storyboard drawing, script writing, use of camera, video shooting, narration recording, video editing and sharing that helped learners master the basic skills, concepts, and use of digital media (Chan et al., 2017). Chan et al. (2017)'s study reflects the focus of this paper which is to demonstrate how the various elements and tasks in a TS project provide multimodal engagement for students.

As discussed previously, multimodality is at the core of TS and TS pedagogies. The use of various modes of meaning to construct and disseminate a narrative is what sets TS apart from other forms of storytelling. The use of TS as formative project-based assessment for a course enables students to have an active and immersive engagement with multiple modes of meaning instead of merely being passive consumers of a multimodal text or ensemble. In the next section, the different modes of meaning as outlined in multimodal theory will be discussed. The modes of meaning provide the framework for the analysis of the students' TS campaign in this study.

\section{THEORETICAL FRAMEWORK}

\section{MULTIMODALITY}

The analysis of students' TS project artefacts in this study is guided by multimodal theory and concepts outlined in this section. Multimodality attends to meaning as it is organized and configured through sets of semiotic resources for meaning making known as modes (Jewitt, 2008). The precise definition of what constitutes a mode varies but "what makes a mode modelike is its availability as a resource for making signs in a social-cultural group" (Kress \& Van Leeuwen, 2002, p. 346). Jewitt and Kress (2003) explain that a mode is perhaps best understood as a "regularised organised set of resources for meaning-making, including, image, gaze, gesture, movement, music, speech and sound-effect" (p. 1).

The New London Group (2000) identified five modes of communication which are visual, linguistic, spatial, aural and gestural. This categorisation and description of the five modes were adapted and expanded upon in Perry (2018) and Periasamy et al. (2016) and the technical and digital mode of meaning (animation, image transitions, hyperlinks, shot types, camera angle) was included to recognise digital texts that are produced using digital tool and are composed of interactive elements. As digital forms encompass a key element in $21^{\text {st }}$ century storytelling, interaction with technical and digital mode of meaning are vital in transmedia storytelling. Hence, the multiple modes of meaning described in this paper are categorised as visual and spatial modes, linguistic modes, gestural modes, audio modes, and technical and digital modes (Perry, 2018; Periasamy et al., 2016). The analysis of the TS project in this study is based on the modes described above. The elements that make up each category of mode is discussed in further detail in the following sections. The use of the following modes of meaning and elements in the design and production TS campaign by the students will be identified and analysed as a method of determining multimodal engagement in this study.

\section{VISUAL AND SPATIAL MODE}

The visual and spatial mode is the visual composition and physical arrangements that make up a text such as objects, spaces (environmental and architectural), images, people, symbols and their colour, layout, size, shape and position (Arola et al., 2014; Jewitt, 2008; The New London 
Group, 2000). As described in Serafini (2014), elements of visual composition include colour, size, scale, position, motifs, symbols, representations, narratives and point of view and "creating any visual image or multimodal ensemble requires the designer or artist to make decisions not only about what to represent, but also how to represent it." (p. 62). Therefore, the use of colour, images, symbols in students' campaign artefacts such as posters, logos and photographs will demonstrate their engagement with visual modes and elements.

Visual narratives are constructed through images that depict narrative elements such as participants, objects, settings and actions and compositional structures refer to "how various elements relate to one another, how they are organized spatially, and their relative position are referred to as composition" (Serafini, 2014, p. 65). In a short film for example, the visual narrative is constructed through the actors (participants), props (objects), locations (settings) and movements (actions) carried out by the actors on screen. The compositional structure in a film is often planned by the production team and visually represented through a storyboard. A storyboard visually and spatially depicts information on actors, their costumes, props and setting and objects and how they are positioned and presented within a shot and scene in the film and aids the production process for all involved in the filming of a scene (Serafini, 2014). Social media pages or profiles such as Twitter, Instagram and Facebook include elements of visual and spatial modes such as colour, layout, profile pictures and logo "which play a big role in how users recognize and understand the contents in these pages" (Arola et al., 2014, p. 6).

\section{LINGUISTIC MODE}

The linguistic mode plays an important part in a transmedia storytelling storyworld, especially if it includes a short film and a book. The linguistic mode usually refers to spoken and/or written and printed words (Arola et al., 2014). Elements of the linguistic mode such as language, writing, speech, dialogue and vocabulary will also be analysed in this study (Jewitt, 2008). The linguistic mode also refers to elements of typography such as font and bold and italics which also play a visual role in adding meaning to a text (Álvarez, 2016). The writing of a script and story, suitable captions and headings for images as well as delivery of dialogue and speech with the right pronunciation and clarity exemplify the use and engagement of the linguistic mode.

\section{AUDIO MODE}

Audio mode as described in this study refers to elements such as voice, tone, accent, sound, sound effect, ambient sounds (Cope \& Kalantzis, 2009). Background music in films, sound effects, songs, and alerts, beeps, and buzzing, whirring and white noises made by digital devices and apps also communicate a meaning and signal to users. In the making of a multimodal, multimedia ensemble or text, the choice of music and sound included by the editor would involve use and engagement with the audio mode of meaning. Actors who deliver dialogues or monologues with the right tone of voice, inflection, accent and volume also demonstrate an understanding of how elements of voice, sound and volume can affect meaning production in a text, especially in storytelling.

\section{GESTURAL MODE}

Elements of gestural mode include body physicality, body language, posture, facial expression, hand gestures and interaction and proximity between people (Arola et al., 2014; The New London Group, 2000). These elements are used in face to face interactions between people and by actors in a short film and also in photographs, art and images of people, animals and animated characters. More recently, facial expressions and gestures are also found in digital 
communication in emoticons, emojis and GIFs. In creative productions such as art, filmmaking and digital graphics and visuals, the artists, filmmakers and designers employ and engage with these gestural modes to communicate various meanings to audiences in combination with other modes of meaning.

\section{TECHNICAL AND DIGITAL MODE}

Technical and digital modes refer to meanings that are constructed through the use of technical and digital equipment, devices and tools. Elements such as camera angle, distance (close up, aerial view) and brightness which are composed in a text through the use of cameras, video cameras, lights and other film and recording equipment make up the technical and digital mode of meaning. Other elements including animation and editing elements such as visual effects that are used to produce texts in a meaningful and interesting manner through digital devices and software are also considered to be elements of the technical and digital mode. In the making of a video, film, animation or multimodal digital texts, creators engage with technical modes through the use of various equipment such as cameras, sound equipment, editing software and digital tools to design, create and edit various visual, spatial, audio and gestural elements so that the text is coherent and cohesive.

The five modes of meaning described above will guide the analysis of the students' TS project. Each artefact will be analysed to identify the use and presence of the different modes of meaning and elements described. The use of more than two or more multimodal elements in the construction process of every artefact produced by the students as part of the TS campaign output will be considered as evidence of multimodal engagement.

\section{METHODOLOGY}

This section will discuss in detail, the methodology of the TS project used in this study including the context of the study and method of data collection and analysis.

\section{CONTEXT OF STUDY}

The TS project was first introduced at a Malaysian public university in Selangor, where the research has been conducted since 2017 as a topic in the Literature and the Media course. Literature and the Media is an elective Citra (liberal) course at the university under the language, communication and literacy domain which is open to students from all faculties and years in the university. The course aims to develop students' knowledge and competencies in English language, literature and media studies. The teaching and learning approach used for the Literature and the Media course is largely influenced by the multimodality and multiple intelligences theory.

The Transmedia Storytelling Campaign (henceforth referred to as TSC) was designed as a formative project-based assessment for the course due to its core elements of incorporating multiple and multimodal platforms in the creation and delivery of a narrative. TS, was thought to be an excellent concept to increase multimodal engagement in undergraduate students. The transdisciplinary nature of TS that incorporates literary, media, marketing, branding and digital technology also made it a suitable subject for a course comprising of undergraduate students across faculties. The following section will explicate the details of the TSC project including the method, the sample population and execution of the different stages of the project as well as the input provided by the lecturer to the students. 


\section{TSC CASE STUDY AND PARTICIPANTS}

Over the years, students have produced many TSCs for the Literature and the Media course at the university. For the purpose of this paper, only one TSC, Hope and Home (2018) has been selected as a case study to identify the multimodal engagement in a TS project as it met all the necessary condition for the investigation. A single case study method was used in this study to allow for an in-depth investigation and rich description and understanding of multimodal engagement in TS projects (Darke \& Shanks, 2002). As each TSC consists of at least three different platforms through which a storyworld unfolds, only one TSC could be chosen for analysis so that the description and analysis can be extensive and in-depth (Baškarada, 2014).

A purposive sampling method was used to select the single case study. The Hope and Home (2018) (henceforth referred to as $H \& H$ ) was selected as it met all the necessary conditions for a single case study of a TS project (Darke \& Shanks, 2002). $H \& H$ was selected from four TSCs produced by a class comprising of 30 students from the university's Faculty of Education, Faculty of Science and Technology and Faculty of Social Sciences and Humanities. The class was divided into four groups for the TSC project with each group consisting of seven to eight members. The $H \& H$ campaign was produced by a group of students who called themselves Le Bien Production. The group comprised seven second year students from the Faculty of Education majoring in Teaching of English as a Second Language (TESL). The group consisted of six females and one male student who were all aged between 21 to 24 years old. $H \& H$ was an exemplary TSC in terms of quality, design, execution and presentation out of all the TSCs presented by the students in that class. The $H \& H$ TSC materials and artefacts were also meticulously documented, compiled and submitted in digital format to the lecturer as instructed allowing for convenient data gathering and analysis.

In the following sections, the Transmedia Storytelling project design, instruments of the study, i.e. the TSC project, its implementation and evaluation criteria will be described in detail.

\section{TRANSMEDIA STORYTELLING PROJECT INPUT}

Students were given three weeks of input by the lecturer on the topic of TS. Interactive lectures and workshop sessions were conducted on the basics of business storytelling and core principles of TS. Case studies of effective and successful TSCs as business storytelling conducted by various organizations and brands were used to help students understand the principles of TS and learn strategies of conceptualizing and implementing TSC. In preparation for the TSC project, students were tasked to conduct a case study of a brand or organization that has used TSC in their business storytelling strategy for branding and marketing. Through this task, students had to identify the principles of TS that are evident in the TSC of their chosen brand and compile a short report on their case study. This helped prepare them towards conceptualizing their own TSC for the university brand as specified in the task.

\section{TRANSMEDIA STORYTELLING PROJECT INSTRUCTIONS}

The students, in their groups of seven to eight people were asked to conceptualize and create a TSC for the purpose of marketing and branding for the university. This added an element of business storytelling to the task, an aspect of storytelling that the students had been taught earlier in the course. The university brand was selected for the purpose of this project as it was a brand that the students were considered to have a deep understanding of. Furthermore, if they needed more information and material on the brand, they could access it easily from various sources on campus.

As TS is essentially multiplatform storytelling, for the TSC, students were asked to create a storyworld that is disseminated through three platforms with short film being a 
compulsory platform they had to complete in its entirety. The short film was chosen as a compulsory component because short film production assessments were found to develop multimodality and other $21^{\text {st }}$ century skills (Perry, 2018). The findings on skills and competencies developed through short film assessments described in Perry (2018) informed this choice in the TSC project design.

Students were given the freedom to choose and decide the other two platforms their narrative would unfold through. Novels, social media pages, events, news articles, websites, apps, or immersive spaces were suggested as possible options. Unlike the short film component, students had to only produce a concept and design for these two other platforms and not produce a complete product.

Since the short film was a compulsory element in their TSC, a short workshop on short film production was conducted for students where they were exposed to basic steps in film production. Students were exposed to resources and digital tools related to digital scriptwriting, storyboard creation, film music, sound editing and film editing. In addition to lectures, tutorials and workshops on TS, each group also had at least one compulsory private consultation session with their lecturer to further refine their ideas and proposals for the story and platform for the TSC. Students also had access to regular discussions via email and text message with their lecturer for further guidance on various aspects of their TSC throughout the entire process from start to completion of their project.

\section{TRANSMEDIA STORYTELLING CAMPAIGN (TSC) CONCEPTUALISATION AND DESIGN}

Students' work on their TSC project was conducted through discussions with their respective group members during and outside of class hours. Small group discussions are considered to be beneficial for collaborative projects as students can exchange ideas and reflect and consider the perspective of others and come up with new ideas to add to their existing knowledge (Lee \& Ertmer, 2006). Students also conducted field work to scout for locations for the filming of their short film. Midway through the planning process of the TSC, students attended a pitching session where the groups pitched their campaign ideas to their peers and the lecturers. Through the application of role play methods as a formative learning approach, the pitching sessions "provide students the experience of concept or advertising pitching that is done in the media world" and "students have the opportunity to seek ideas and get feedback on their creative decisions from the lecturer and other groups in the class so that they can further make adjustment to their plans and improve their project" (Perry, 2018, p. 222).

In total, the students were given six weeks to conceptualise, design, pitch, execute, complete and present the project. In that time, they were requested to document and compile all artefacts (notes, scripts, storyboards, presentation slides, photographs, images, posters, short film video, etc) in digital format. After presenting their completed TSC to the lecturer and peers at the end of semester, students had to submit their compiled TSC artefacts to the lecturer via the course Google Classroom site. Finally, students had to submit a reflection on their TSC project experience through an online Google Form provided to them by the lecturer after completion of the project.

\section{DATA COLLECTION METHOD}

The data used for this study comprised student presentations, TSC campaign notes, materials and artefacts and student reflections. Student presentations include campaign pitching and final presentations. TSC campaign artefacts include scripts, storyboards, rough notes, sketches, presentation slides, photographs, screen shots, posters, social media pages, film trailers, short films and videos. 
Data was collected through observation of in class student group discussions of their TSC campaign ideas, pitching presentations and campaign presentations, as well as taking observation notes, photographing, video recording of these presentations. The TSC artefacts were collected in digital format from students using the Google Classroom site.

Student reflections were also used as additional data. They are a useful pedagogical strategy as they enable both the students and the teacher to understand the thought processes involved in understanding the new concepts and skills involved in a lesson (Colley et al., 2012). Reflections were collected via an online Google Form that was designed by the lecturer. They were done after the completion of the project upon which the students could reflect on the learning goals that they had achieved through the project and also evaluate their strength and weakness and recognize opportunities to improve themselves for the future. It was also collected to promote reflective and critical thinking. As noted by Tang (2016), "students' process of finishing a digital storytelling project" such as the TSC campaign, "helps to develop a new understanding of the world around each student by means of critical self-reflection" ( $p$. 573).

\section{DATA ANALYSIS METHOD}

The data collected in this study was analysed for evidence of students' engagement with multiple modes of meaning outlined in the theoretical framework in their completion of various tasks as part of the TSC. Observation notes, photographs and video recordings of students TSC output in the form of pitching, campaign presentations and TSC artefacts were collated and analysed for evidence of interaction with and use of visual and spatial, linguistic, gestural, audio and technical and digital modes of meaning. This was done by observing students in class and during presentations and noting down students' explanations and elaborations on planning and tasks executed towards the completion of the TSC. The completed project and the artefacts submitted were also analysed to determine the multiple modes employed in the construction of the artefacts.

The analysis and interpretation of data in this study was based on the deductive approach of conclusion drawing where meaning is drawn from the data collected and evidence is built in a logical manner based on the interpretation of the data (Darke \& Shanks, 2002). To present the multimodal engagement present in the TSC artefacts, a descriptive and interpretive approach was employed as the method of analysis. Darke and Shanks (2002) noted that the interpretive researcher of a case study is "presenting their interpretation of the interpretation of others and the strength of analysis derives from the strength of the explanation of the phenomena based on the interpretation of data" (p. 118). In this approach, it is important to acknowledge the influence of the researcher and the context as data collection and analysis are influenced by the researcher's background and characteristics. As the researcher was also the course lecturer, any resulting biasness and subjectivity of the observation of students and analysis of artefacts was acknowledged as a possible limitation to this case study. The inclusion of student reflection was an effort to counteract the effects of biases.

For the analysis of the TSC artefacts, firstly, the type of platforms or media (short film, book, social media page, etc.) used in the TSC was identified. Artefact-oriented analysis which is the descriptive analysis of student artefacts enables the identification of skills and resources used in the learning activity (Wong et al., 2012). In this study, each of the TSC artefacts such as scripts, storyboards, photographs, video recordings and short films was then analysed to identify the use and operation of two or more modes of meaning in its design and construction.

The use of images, logos, patterns colours, objects, buildings, spaces and geographical settings to communicate a specific meaning in the artefacts were analysed and identified as engagement with the visual and spatial mode of meaning. Written works utilising language 
including scripts, captions, stories, posts as well as oral productions such as delivery of dialogues and oral presentations were analysed for evidence of engagement with the linguistic mode. The use of sound and music in the TS campaign artefacts in a meaningful and effective manner to communicate meaning in combination with the other modes of meaning was also analysed and identified as demonstration of engagement with the audio mode.

The use of appropriate physical movements, gestures, facial expressions to express the intended emotions and communicate meaning more effectively was interpreted as engagement with the gestural mode. Finally, evidence of the use of digital software, tools and technical equipment in the design and production process of the TS campaign to successfully complete and present the campaign artefact was considered as evidence of engagement with technical and digital mode of meaning. All artefacts submitted by the students as part of their TS campaign were analysed for the use of multiple modes of meaning and each mode was identified, interpreted and discussed in the findings section.

In addition to analysing the artefacts, the various tasks involved in the conceptualisation, design and production of each platform and the elements in each platform were identified and listed. Every task conducted for each platform such as the pre-production, production and post-production stages in the short film production, the design, images and captions in the book and social media platform was identified, charted onto a table format, analysed and described. The findings of this analysis were charted in a matrix to present a summary of students' engagement with multimodal elements in the production and execution of a TSC project. The matrix shows every mode of meaning that students engaged with in the creation of each artefact and the extent of multimodal engagement as a whole in the creation of the entire campaign.

Finally, the reflections submitted online via Google Form by the students were collated, coded and analysed to reveal students' views on the skills and knowledge obtained through execution of a TSC. The reflections were read, and comments about the TSC tasks were selected and analysed. A thematic approach was employed for this analysis based on the skills identified by students. Key points raised by each student including the skills and knowledge gained and perception of TS were interpreted, identified and presented in a table format.

In the next section, the findings of the selected case study of the TSC conceptualised, designed and produced by the students (Le'Bien Productions) entitled, Hope and Home (2018) will be presented.

\section{FINDINGS OF HOPE AND HOME (2018) TRANSMEDIA STORYTELLING CAMPAIGN}

\section{HOPE AND HOME SYNOPSIS AND STORYWORLD}

The Hope and Home storyworld revolves around the character of Ayu Ajma'in, who was raised by her grandfather, Tokwan, after her parents died in a car accident when she was a baby. The public university has a special place in Ayu's heart because it was the alma mater of both her parents as well as the place where they both met and fell in love. Ayu then begins to dream of securing a place to pursue her tertiary education at the university but also is concerned about leaving her unwell grandfather behind to pursue her studies. Ayu finally does become a student at the university but finds life away from home quite challenging at first. As an only child raised by her grandfather in a village, she has difficulty making friends and is bullied. She starts to regret leaving home and the death of her grandfather sends her over the edge and she sinks to severe depression. She is rescued by friends who care for her and she realizes that she is not alone. 
Surrounded by good and supportive friends, her university life gets better and she does well in her studies and eventually graduates. In her Instagram page, she shares the ups and downs of her life in university with her followers. After graduation, Ayu becomes a writer and motivator to young adults. She publishes a self-help, motivation diary for young adults, using anecdotes and life quotes that helped her get through tough times. She later discovers the love letters her parents wrote to each other while they were in university and publishes a book Dear Love that chronicles her parents' love story. The synopsis of this story was also presented in a visual form by the students during the pitching session as seen in Figure 1.

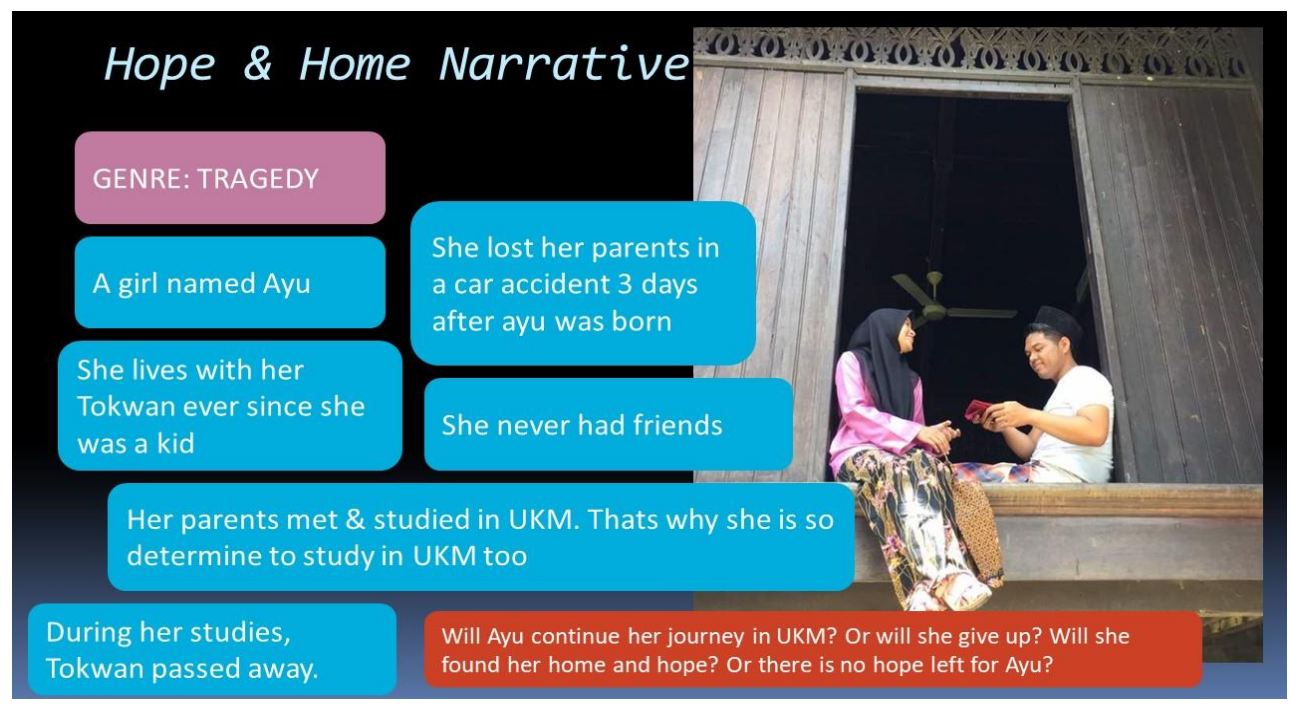

FIGURE 1. Graphic visualization of Hope and Home narrative

\section{HOPE \& HOME TRANSMEDIA NARRATIVE PLATFORMS}

The $H \& H$ campaign is made up of three components or platforms as seen in Figure 2. As per the requirement of the task description, a short film was a compulsory component. In addition to the short film, the students had to conceptualise two other platforms of their choice through which they could tell their story. However, it is important to note that only the short film was a full-length production while the other two platforms were merely proposed concepts and not produced in entirety. In the case of the $H \& H$ campaign, in addition to the short film, the students chose to extend their narration of the storyworld through books and social media platform.

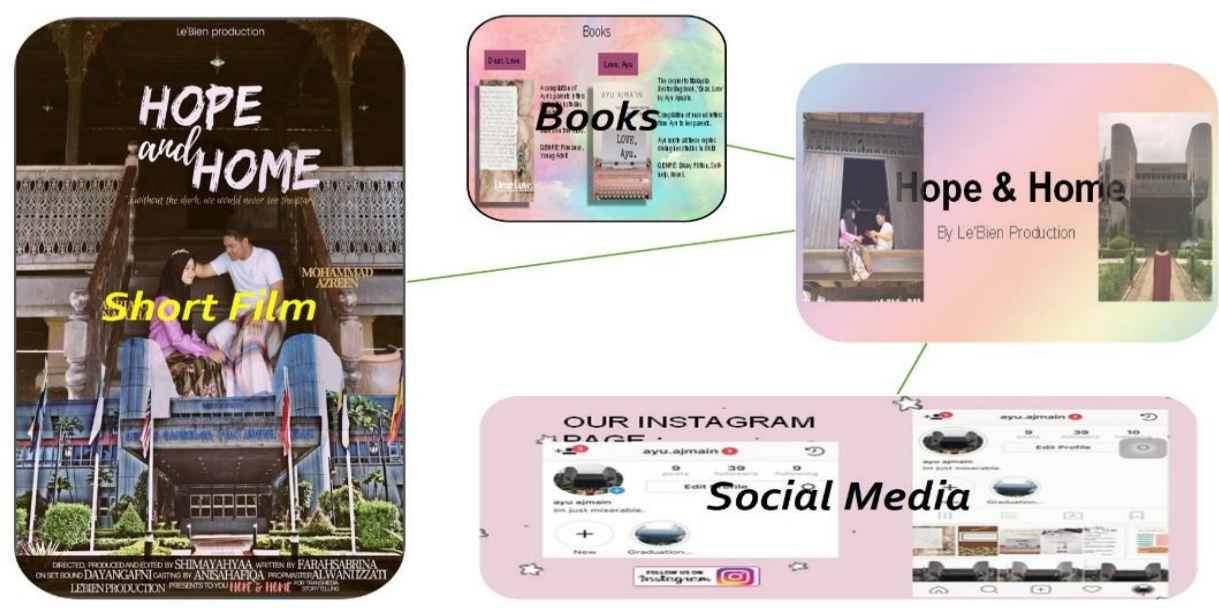

FIGURE 2. Hope and Home transmedia storytelling campaign platforms 
SHORT FILM

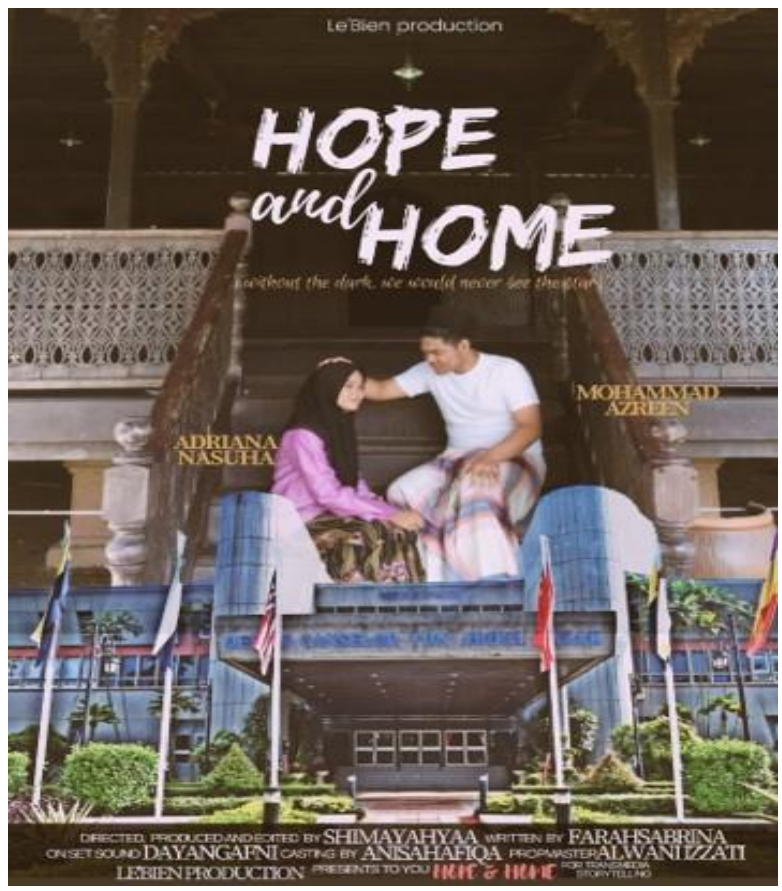

FIGURE 3. Poster of Hope and Home short film

The short film component of the TSC portrays Ayu's life with her grandfather and her dreams of getting into her parents' alma mater and subsequently her journey as she begins a lonely and challenging life as a university student and how she overcomes these challenges. Figure 3 shows the poster that the students created for the short film. The short film was produced and made available in digital form and can be found at the YouTube platform (Shima, 2018).

\section{SOCIAL MEDIA PAGE}

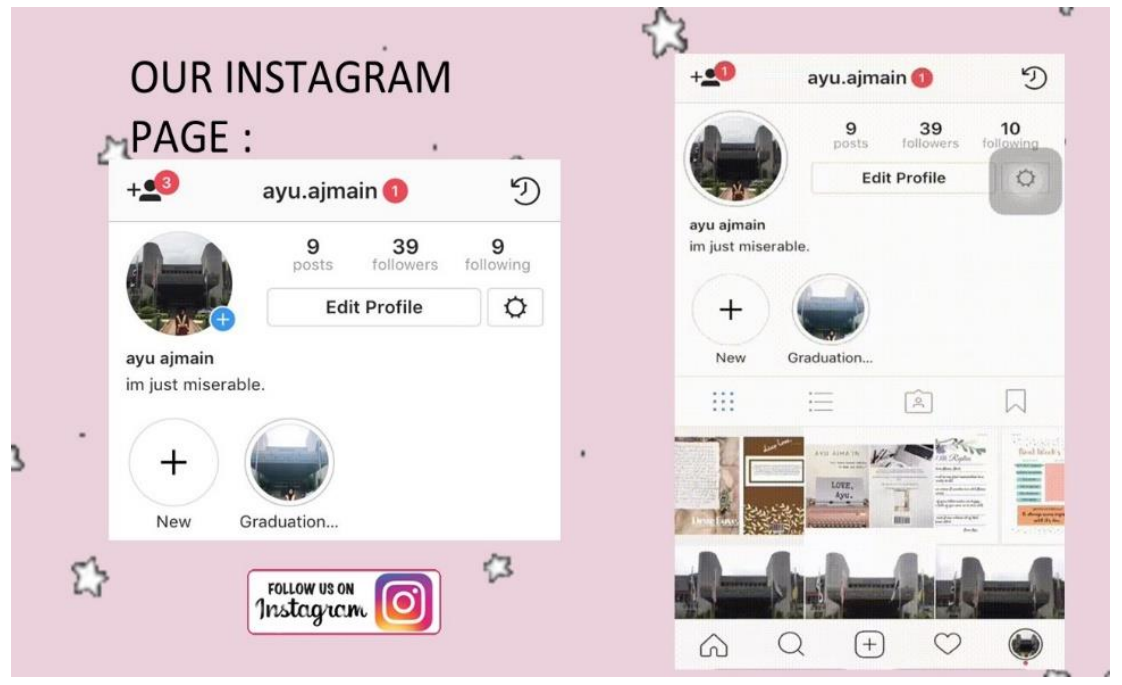

FIGURE 4. Screenshot of Ayu's Instagram page

The social media page was another platform that the students proposed and conceptualized. The students created a mock Instagram account, complete with images and captions as seen in Figure 4. In the social media page, Ayu shares the ups and downs of her life 
in university and her happy moments with her friends in her Instagram page with her followers. The Instagram page narrates Ayu's life in university after she finds her way following her breakdown after losing her grandfather and her way in life. The Instagram page chronicles her experiences up to her graduation day.

\section{THE BOOKS}

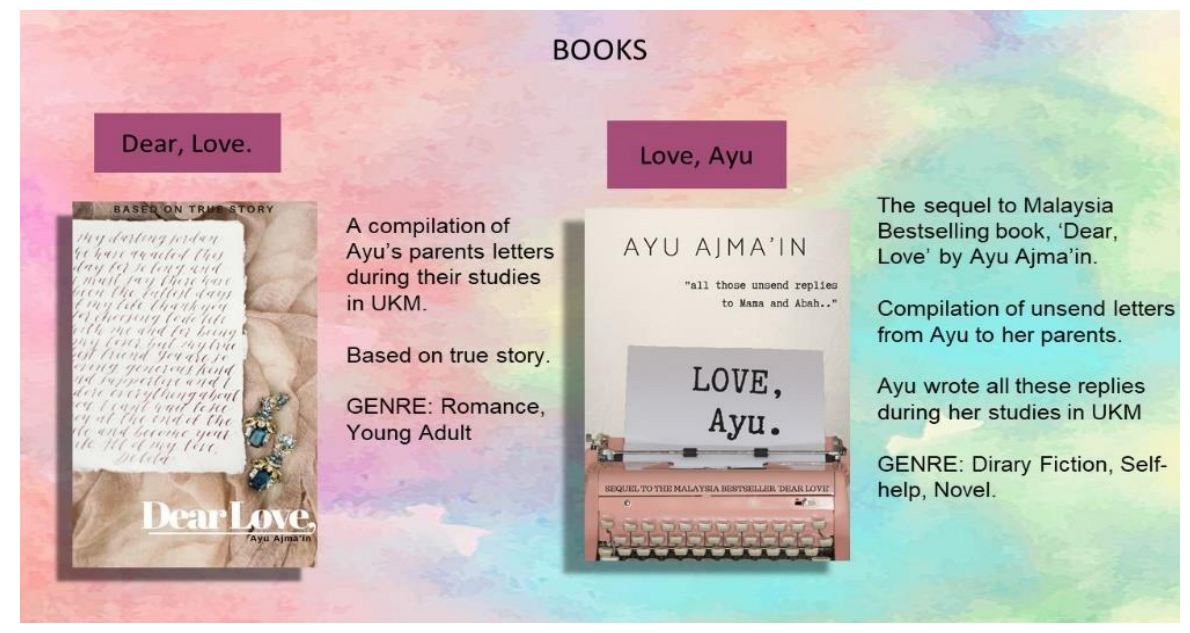

FIGURE 5. Screenshot of Ayu's books

The books are the third platform in which the storyworld of Hope and Home unfolds through. The books present Ayu's life journey after she graduates. After graduation, Ayu becomes a writer and publishes two books. The first book published is Dear Love, a romance for young adults. Dear Love is based on the true story of Ayu's parents and consists of a compilation of love letters that her parents exchanged while in university. This book provides a glimpse into the lives of Ayu's parents, specifically their romantic relationship and acts like a prologue to Ayu's story in the $H \& H$ storyworld.

The second book is Love, Ayu, a self-help diary/journal that contains life lessons, motivational quotes from Ayu. Ayu taps from her own experiences and life journey to write this book.

\section{DISCUSSION OF FINDINGS}

\section{TASKS AND MULTIMODAL ENGAGEMENT IN SHORT FILM PRODUCTION}

The short film production process is made up of three phases: pre-production, production and post-production. The pre-production phase involves the conceptualization of the story for the short film, scriptwriting, and casting, selection of film location, and general planning of the film shoot process and schedules. In the production phase, "students need to have identified a suitable location for the scene and the props and costumes needed" (Perry, 2018, p. 224) and gather all the needed equipment, props and people and shoot their short film. In the postproduction phase, students edit the film and also create a poster for their short film.

The development of the $H \& H$ short film involved all these phases. After having conceptualized the storyworld, the students began pre-production tasks where they developed a script for the short film aspect of the campaign. The script is among the artefacts produced and submitted for the campaign in this pre-production section. The modes that students are found to have engaged in the production of the script will be identified and discussed in the next section. 


\title{
PRE-PRODUCTION: SCRIPT/SCREENPLAY
}

The development of the script or screenplay involved having a clear idea of the film's genre, identifying the setting for the various scenes of the film, designing the plot and identifying characters needed in the film. Below is an excerpt from the $H \& H$ short film script written by the students.

\section{Scene 1 AYU'S OFFICE}

The camera focus on her family's picture in the frame

$$
\begin{aligned}
& \text { AYU: This is Mama and Abah. Their smiles are } \\
& \text { the biggest blessing in my life. } \\
& \text { I really love them. But God loves them more... }
\end{aligned}
$$

\section{Scene 2 PARENTS INVOLVED IN AN ACCIDENT \\ AYU: Mama and Abah got into a car accident \\ 3 days after I was born. Tokwan said, it was a \\ miracle. It was impossible for me to survive in \\ that car accident. But I did. \\ I don't know if that was a good thing.}

\author{
Scene 3 PADDY FIELD \& TOKWAN'S HOUSE \\ AYU: Fragile, frail but fiery \\ That's what described me as a whole \\ My life was once a wreckage. \\ It's like a storm passed through. \\ Not even a tiny bit of mercy was left. \\ Mama and Abah were \\ gone.
}

The excerpt demonstrates how the students have produced a film script to present the story and its characters effectively. In doing so, they are seen to be actively engaging with the linguistic mode of meaning and developing their writing skills. The use of the right words to describe an event and convey emotions demonstrates the engagement with the language in a deep and effective manner. In the script, selection of suitable settings, locations and spaces for scenes such as Ayu's office, paddy field and Tokwan's house indicates that the students have engaged with and put a lot of thoughts into the visual and spatial modes. The office setting is used to inform the viewers that Ayu is now a successful professional while the setting of a paddy field reveals Ayu's humble, village girl background. The note in the script about the camera's focus in 1\#AYU'S OFFICE scene demonstrates students' knowledge and ideas on elements of the technical and digital mode for the filming of the scene. Students demonstrate that they know how to utilise a technical equipment such as the camera to focus on the photo frame so that a specific message is communicated. The combination of technical modes of the type of shot, angle and focus and the visual element of an object/prop in the scene shows the ability to communicate meaning multimodally.

\section{PRE-PRODUCTION: PROPS AND SYMBOL}

The creative and critical decisions about objects, props and symbols to include in the short film demonstrate a high level of engagement and understanding of visual modes of meaning by the students. Observation and analysis of students' presentations at the pitching and analysis of the completed short film reveal that the students have chosen to incorporate specific visual 
elements in the short film to communicate specific meanings within the narrative to enhance the storytelling and reinforce the branding aspect of the TSC. The students chose to include buildings (university main hall) and symbols such as the red university scarf and the acceptance letter which have special significance to the character Ayu to evoke the intended emotions in viewers. Such use of visual elements demonstrates an engagement with the visual mode (Serafini, 2014). Additionally, the students also displayed competency of literary devices in their understanding and effective use of symbolism in the story. Figure 6 shows examples of symbols used in the short film.

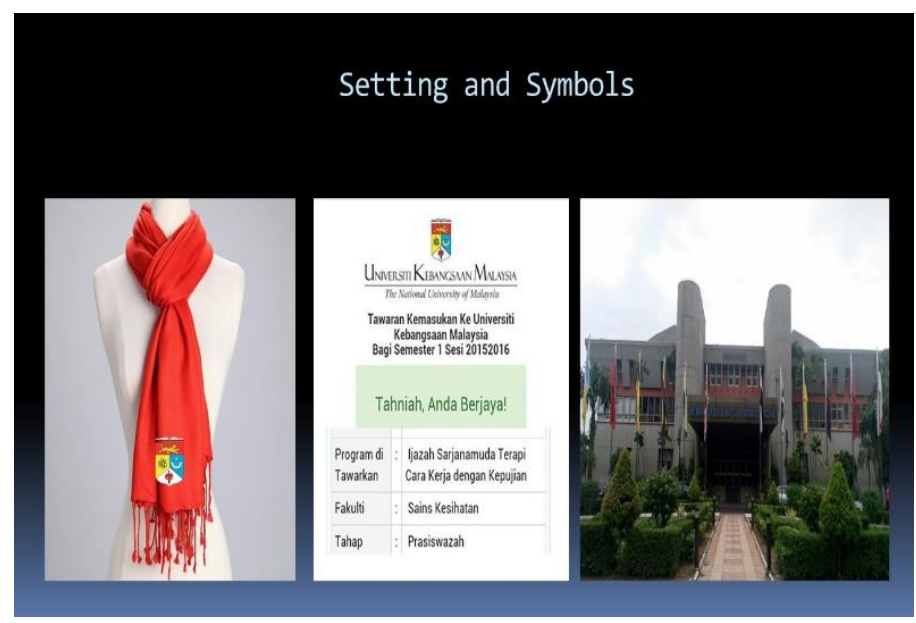

FIGURE 6. Symbols used in Hope and Home short film

\section{PRE-PRODUCTION: STORYBOARD}

After developing the script and deciding on the visual compositional structure including setting and symbols for the short film, the $H \& H$ team developed a storyboard for the short film to help the entire production team visualize the different scenes in the film. The storyboard helps the director, actors and crew understand the scenes, their positions and also help crew know where the props should be in each scene. The storyboard was developed using the online app Storyboard That and presented to peers and the lecturer during the pitching.
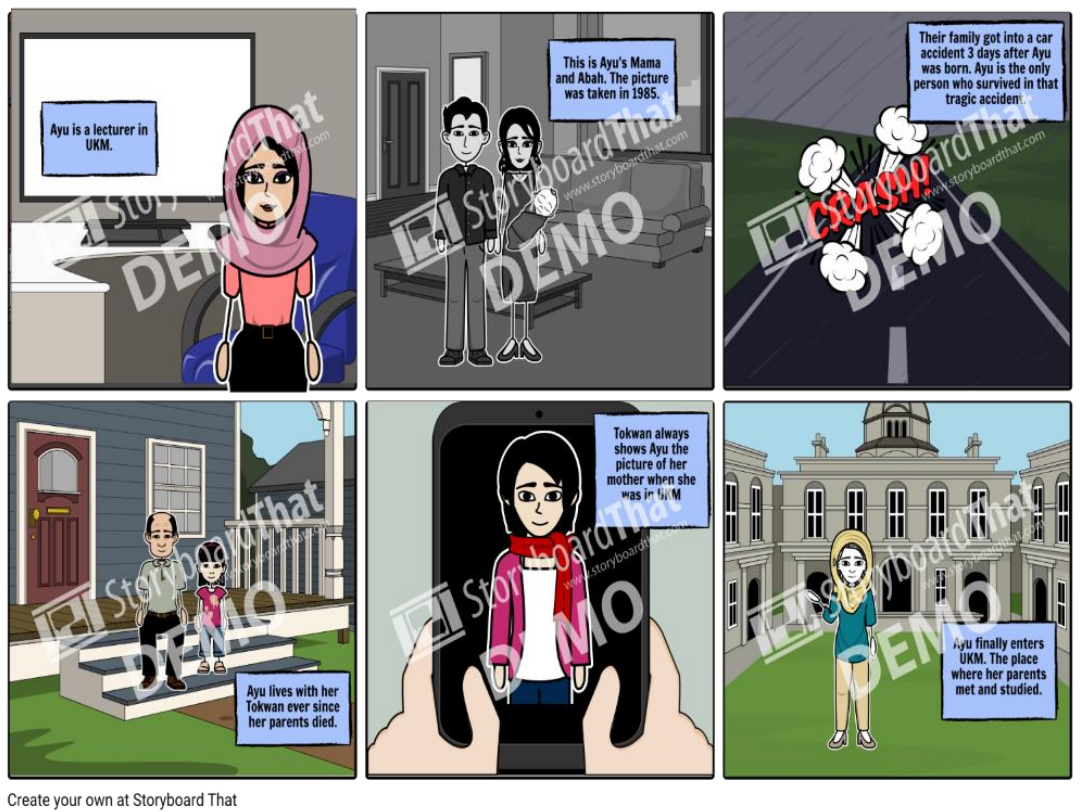

FIGURE 7. Storyboard for Hope and Home short film 
Observations and analysis of the storyboard show not only engagement with digital tools such as storyboard apps but also engagement with visual and spatial modes through the visualization of shots and scenes in the film. Cinematography aspects such as close up, long shots and angles depicted in the storyboard demonstrate that the students utilised the visual and spatial modes in combination with technical mode of meaning to construct the intended meaning in their film scenes. The clear and informative captions in each frame show effective use of the linguistic mode.

\section{PRODUCTION: DIRECTION, ACTING, MAKE-UP AND COSTUME}

Analysis of the short film reveals that the short film director's high level of engagement with visual and spatial, linguistic and gestural modes to ensure each scene was enacted in the way she envisioned it to be. To communicate her vision to the crew in an effective manner, the director would have to use the right words, tone of voice, gestures and facial expressions. The short film was found to have a variety of shot types and angles revealing the director's understanding of technical and digital modes of meaning as well as the skills of the camera and technical crew to film the scenes in accordance to the directors' instructions.

The acting in the short film was well done revealing the actors' effective use of visual, linguistic, audio and gestural modes to deliver dialogues and communicate emotions, tone and mood needed for each scene. Similarly, the make-up, costume and props were found to have engaged with visual and spatial and gestural modes in ensuring that every aspect looked appropriate for each scene. For example, Ayu was dressed in corporate attire in the beginning scenes in the office and in traditional Malay baju kurung in scenes with her grandfather in the village. These costume choices in the film demonstrate that the students understand that such visual elements can communicate meaning about the character to viewers.

The overall production quality of the short film in terms of cinematography, brightness and sound was found to be very good. The camera, light and sound crew demonstrated engagement with visual, spatial, audio, gestural and technical and digital modes in operating the various image and sound recording equipment, software and devices needed to ensure the scene and actors are captured in accordance to the script and the director's instructions.

\section{POST PRODUCTION: EDITING \& POSTER DESIGN}

The completed short film submitted to the lecturer contained all the elements found in a motion picture such as opening credits which contained the Le Bien Production name and the film title Hope and Home. The film included suitable sound effects and background score music to elicit the appropriate emotions and feelings towards the story from viewers. For example, the scene where a depressed, suicidal Ayu walks up the tower included the sound effect of a loud thumping heart, giving a tone of grim suspense to the viewers. The choice of such sounds and music inserted at appropriate parts of the film reveals a high degree of knowledge of the audio mode of meaning. All the scenes in the films were edited seamlessly. These aspects of the film demonstrate an engagement with the technical and digital mode through the use of film and sound editing software. The use of subtitles throughout the film and acknowledgements in the closing credits reveals the use of the linguistic mode via digital tools.

The analysis of the students' short film poster seen earlier in Figure 3 shows their engagement with the digital modes and various visual elements such as colour and font and linguistic elements to choose the most suitable titles and quotes to include in the poster. The analysis of different tasks conducted by the students to produce the short film and its artefacts reveals that the students had engaged with various modes of meaning in all three stages of the short film production. 


\section{TASKS AND MULTIMODAL ENGAGEMENT IN BOOK PRODUCTION}

As mentioned, as part of TS, the storyworld of $H \& H$ is also presented through books. For the book component of the TSC task, the students presented the book concept, genre, design and sample excerpts. In producing these elements, the students were found to have engaged with visual, linguistic and digital modes of meaning. Analysis of the book cover, content design and excerpts, reveals students' understanding of the visual mode conventions of book cover styles and genre. Narrative elements and images in the book cover show engagement with linguistic and visual modes. The students have used digital software to design the book covers, choosing the right images, colours, title and quotes to represent the style of a book cover for the right genres. The engagement with visual, digital and linguistic modes is evident through the analysis of the book cover design and sample excerpt as shown in Figure 8.

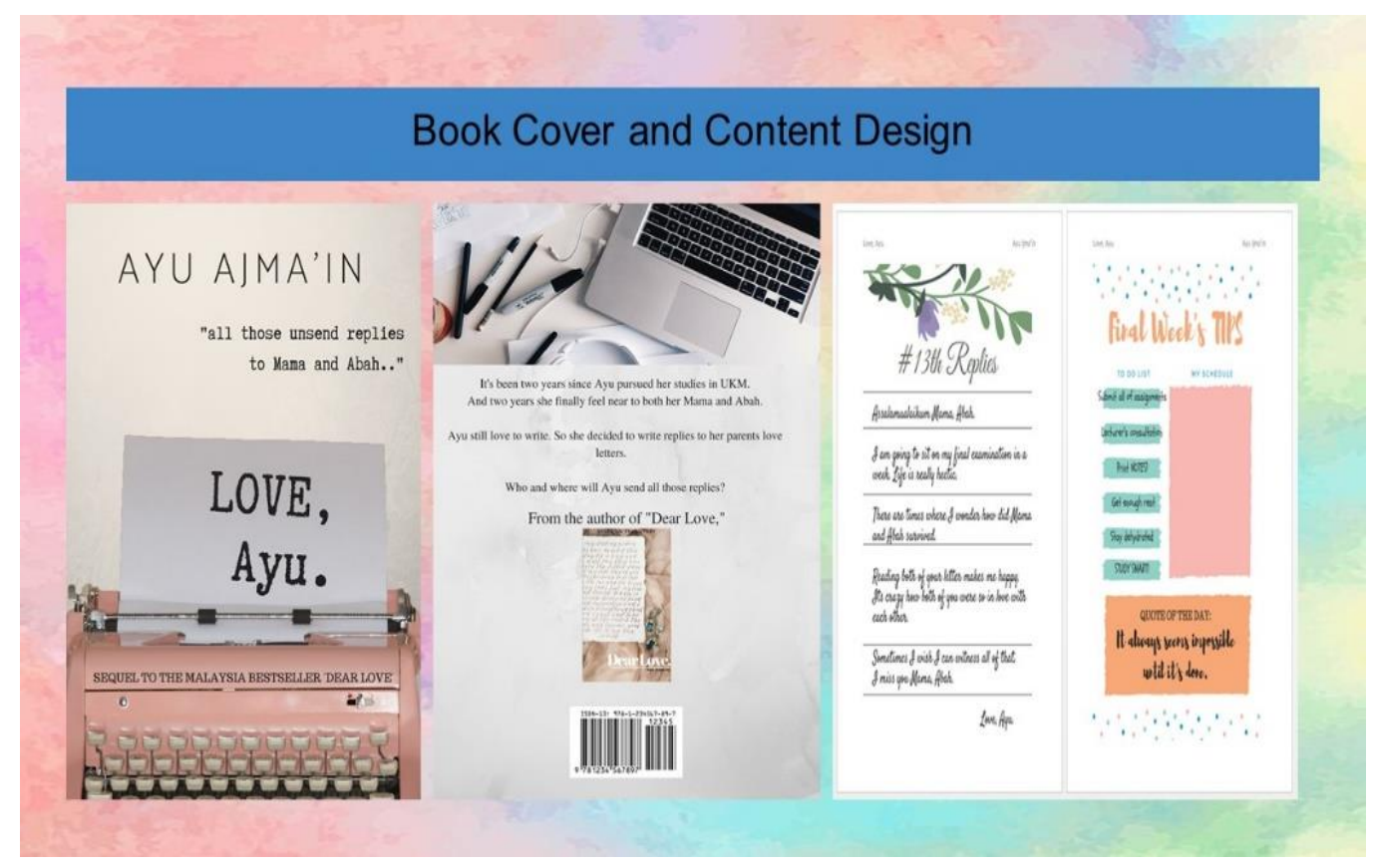

FIGURE 8. Cover design and excerpts of Love, Ayu book.

\section{TASKS AND MULTIMODAL ENGAGEMENT IN INSTAGRAM SOCIAL MEDIA PAGE DESIGN}

The third platform for the $H \& H$ narrative chosen by the students was the social media page. The students created an Instagram account and designed a page where Ayu's character posted images and accounts of her university life. The students demonstrated the digital, visual and linguistic literacy through the use of Instagram to present the narrative of $H \& H$. As digital natives, the students tapped into their own knowledge and experience as social media users and presented the story of Ayu through posts and Instagram stories to be consumed digitally by followers. This was evident in the screen capture of the Instagram page shown in Figure 9. 


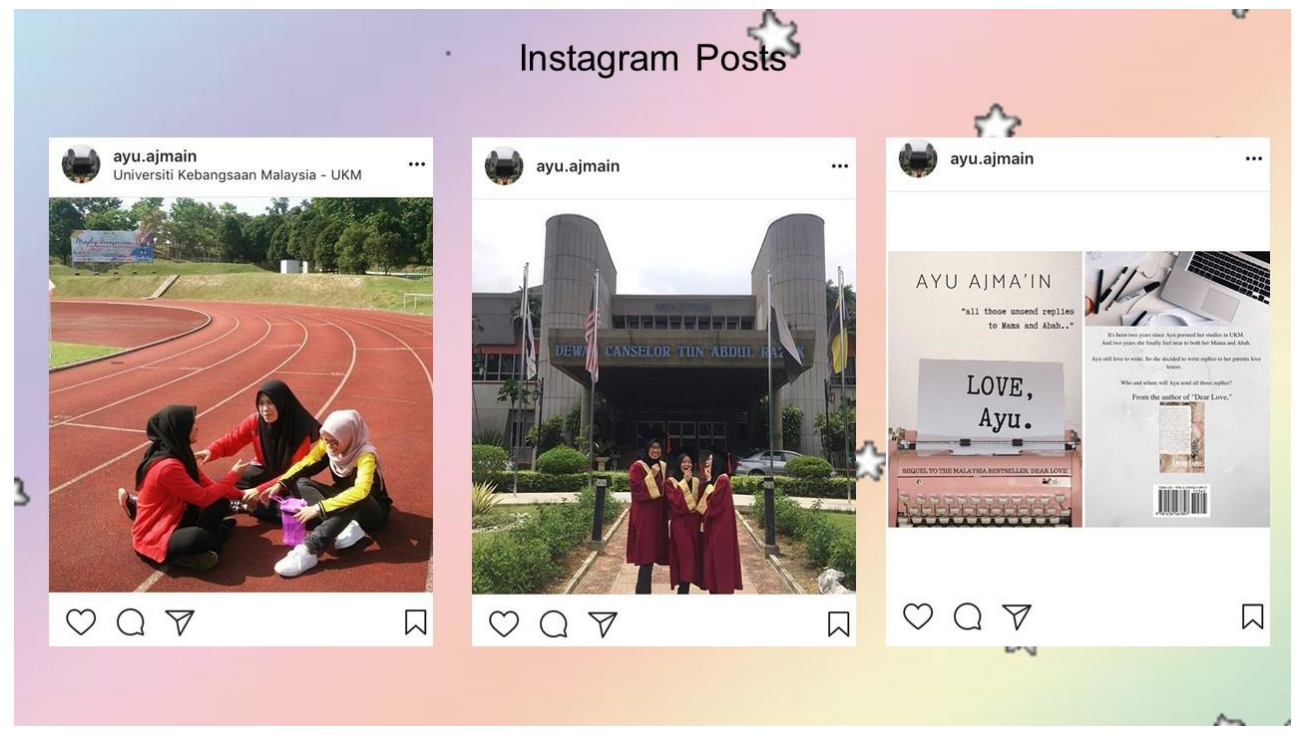

FIGURE 9. Screen shots of Ayu's Instagram posts

The observation and analysis of the $H \& H$ TSC which was chosen as a case study of TSCs for the Literature and the Media course has revealed the students' ability to engage with multiple modes of meaning. In accordance to Chan, Churchill and Chiu's (2017) observations on benefits of TS for developing multimodal literacy, the university students were able to engage with visual and spatial, linguistic, gestural, audio and technical and digital modes through the different tasks they conducted as part of their TSC project. Table 1 summarizes all the modes of meaning that students have engaged with in the completion of every task performed to conceptualise, design and produce all platforms in the TSC project.

TABLE 1. Matrix for multimodal engagement through transmedia storytelling campaign project

\begin{tabular}{|c|c|c|c|c|c|}
\hline MODES OF MEANING & $\begin{array}{l}\text { VISUAL / } \\
\text { SPATIAL }\end{array}$ & LINGUISTIC & GESTURAL & AUDIO & $\begin{array}{l}\text { TECHNICAL/ } \\
\text { DIGITAL }\end{array}$ \\
\hline $\begin{array}{l}\text { TRANSMEDIA } \\
\text { STORYTELLING } \\
\text { PLATFORMS \& TASKS }\end{array}$ & & & & & \\
\hline \multicolumn{6}{|l|}{ SHORT FILM } \\
\hline \multicolumn{6}{|l|}{ Pre-Production } \\
\hline Story & $\mathrm{X}$ & $\mathrm{X}$ & $\mathrm{X}$ & $\mathrm{X}$ & $\mathrm{X}$ \\
\hline Script/Screenplay & $\mathrm{X}$ & $\mathrm{X}$ & $\mathrm{X}$ & $\mathrm{X}$ & $\mathrm{X}$ \\
\hline Storyboard & $\mathrm{X}$ & $\mathrm{X}$ & $\mathrm{X}$ & & $\mathrm{X}$ \\
\hline Pitching & $\mathrm{X}$ & $\mathrm{X}$ & $\mathrm{X}$ & $\mathrm{X}$ & $\mathrm{X}$ \\
\hline \multicolumn{6}{|l|}{ Production } \\
\hline Location \& Set & $\mathrm{X}$ & & & & \\
\hline Acting & $\mathrm{X}$ & $\mathrm{X}$ & $\mathrm{X}$ & $\mathrm{X}$ & \\
\hline Camera & $\mathrm{X}$ & & $\mathrm{X}$ & $\mathrm{X}$ & $\mathrm{X}$ \\
\hline Direction & $\mathrm{X}$ & $\mathrm{X}$ & $\mathrm{X}$ & $\mathrm{X}$ & $\mathrm{X}$ \\
\hline Costume and Make up & $\mathrm{X}$ & & $\mathrm{X}$ & & \\
\hline \multicolumn{6}{|l|}{ Post-Production } \\
\hline Film Editing & $\mathrm{X}$ & $\mathrm{X}$ & $\mathrm{X}$ & $\mathrm{X}$ & $\mathrm{X}$ \\
\hline Sound Editing & $\mathrm{X}$ & $\mathrm{X}$ & $\mathrm{X}$ & $\mathrm{X}$ & $\mathrm{X}$ \\
\hline Film Poster Design & $\mathrm{X}$ & $\mathrm{X}$ & & & $\mathrm{X}$ \\
\hline
\end{tabular}




\begin{tabular}{|c|c|c|c|c|c|}
\hline \multicolumn{6}{|l|}{ BOOK } \\
\hline Story & $\mathrm{X}$ & $\mathrm{X}$ & & & \\
\hline $\begin{array}{l}\text { Cover and content artwork } \\
\text { and images }\end{array}$ & $\mathrm{X}$ & $\mathrm{X}$ & $\mathrm{X}$ & & $\mathrm{X}$ \\
\hline Book excerpts & $\mathrm{X}$ & $\mathrm{X}$ & & & $\mathrm{X}$ \\
\hline Content layout & $\mathrm{X}$ & $\mathrm{X}$ & & & $\mathrm{X}$ \\
\hline \multicolumn{6}{|l|}{ SOCIAL MEDIA } \\
\hline Story & $\mathrm{X}$ & $\mathrm{X}$ & $\mathrm{X}$ & $\mathrm{X}$ & $\mathrm{X}$ \\
\hline Instagram account set up & $\mathrm{X}$ & $\mathrm{X}$ & & & $\mathrm{X}$ \\
\hline Instagram Posts & $\mathrm{X}$ & $\mathrm{X}$ & & & $\mathrm{X}$ \\
\hline Instagram Photos & $\mathrm{X}$ & $\mathrm{X}$ & $\mathrm{X}$ & $\mathrm{X}$ & $\mathrm{X}$ \\
\hline Instagram Videos & $\mathrm{X}$ & $\mathrm{X}$ & $\mathrm{X}$ & $\mathrm{X}$ & $\mathrm{X}$ \\
\hline
\end{tabular}

As displayed in Table 1, the students had the highest engagement with visual and spatial, linguistic, and technical and digital modes of meaning in all three platforms. They had lesser engagements with gestural and audio modes as the book and social media platform employed less of these modes compared to the film platform. The TSC project had therefore provided an engaging multimodal learning experience for the students as revealed in the analysis of their tasks and completed work.

\section{STUDENT REFLECTIONS}

As outlined earlier, student reflections on the TSC project were also collected. A thematic analysis of the reflections provided an insight into a multimodal engagement they had as well as other knowledge and skills developed through the TSC project. Table 2 contains the reflections in the left column and the knowledge, key points and skills developed through the TSC, interpreted based on their comments, in the right column.

TABLE 2. Findings based on students' reflections on TSC project

\begin{tabular}{|l|l|}
\hline Student Reflections & Key Points and Skills Identified \\
\hline $\begin{array}{l}\text { I will never view in the same after taking this course } \\
\text { as I am likely to search for every single thing that } \\
\text { contributes to meaning. }\end{array}$ & $\begin{array}{l}\text { Understanding of multimodal construction of } \\
\text { meaning in media texts. }\end{array}$ \\
\hline $\begin{array}{l}\text { I think Transmedia storytelling can be used as a } \\
\text { multiliteracies teaching strategy where we can attract } \\
\text { students to learn literature in a fun way. }\end{array}$ & $\begin{array}{l}\text { Recognition of TS as a pedagogy for multiliteracy } \\
\text { to engage learners. }\end{array}$ \\
\hline $\begin{array}{l}\text { I think students can learn better through this kind of } \\
\text { approach as it is more fun and enjoyable. }\end{array}$ & TS as a fun and enjoyable teaching tool. \\
\hline $\begin{array}{l}\text { I think it benefits me as a student as I can use various } \\
\text { kinds of modes to engage with literature text. }\end{array}$ & $\begin{array}{l}\text { Able to use multiple modes of meaning to read } \\
\text { and understand literary texts. }\end{array}$ \\
\hline $\begin{array}{l}\text { Transmedia Storytelling as a teaching tool is great } \\
\text { for teacher to explore and share the content with the } \\
\text { students effectively. Creating transmedia storytelling } \\
\text { is entertaining and educational and this is a creative } \\
\text { and active teaching method that creates critical } \\
\text { thinking and empowers the students. }\end{array}$ & $\begin{array}{l}\text { TS is an effective, active learning teaching tool } \\
\text { learner autonomy. }\end{array}$ \\
\hline $\begin{array}{l}\text { Different people use different method of study so by } \\
\text { engaging multimodal literacies, it could help students } \\
\text { to find it more engaging through their own method of } \\
\text { study }\end{array}$ & $\begin{array}{l}\text { Multimodal pedagogies benefit all learners with } \\
\text { diverse abilities and learning styles. }\end{array}$ \\
\hline
\end{tabular}

Analysis of these reflections reveals that students had experienced a multimodal engagement through the completion of the TSC. As the students in the case study comprised 
of second year students from the Faculty of Education, their reflections revealed their appreciation of TS as an effective multimodal pedagogical tool. They also found TS to be an active learning tool that is fun, enjoyable and suitable for all kinds of learners. This analysis reinforces the findings based on the TSC artefacts that the TSC enabled students to engage with multiple modes of meaning as well as develop various other skills and competencies.

\section{CONCLUSION}

This paper has detailed the use of TS as a pedagogical tool for multimodal engagement for undergraduate students. The single case study analysis reveals that students engaged with multiple modes of meaning and used a short film, book and social media as narrative platforms to produce a TSC. It is important to highlight that the multimodal engagement students had through the TS project was not only as users and interpreters of meaning but more importantly, as creators of meaning. The students collaboratively created various artefacts for the TSC including scripts, storyboards, posters and book covers that employed multiple modes of meaning in their design and content. The creative aspect of the task therefore provides a much deeper and more active engagement with multiple modes of meaning enabling them to further develop and increase their levels of multiple literacies.

This study has shown TS to be an effective pedagogical tool that can be applied as a formative assessment to enable tertiary students to critically and skilfully engage with visual and spatial, linguistic, audio, gestural, and technical and digital modes of meaning. This study has also revealed that a comprehensively designed TS project can be a holistic learning tool that can also develop creativity, critical thinking and provide an active, fun and engaging learning experience for students. The findings of this paper are hoped to pave the way towards identifying and understanding the diverse applications and potential contributions of TS pedagogies in the $21^{\text {st }}$ century higher education contexts. Future applications of TS pedagogies can focus on more holistic development of learner such as character building, and physical, mental and emotional well-being in learners.

\section{ACKNOWLEDGEMENT}

This work was supported by a Young Researcher Grant (Geran Galakan Penyelidik Muda) GGPM2016-075 from The National University of Malaysia. Parts of this research was presented as a conference paper at the 9th International Conference on Multimodality at the University of Southern Denmark, Odense, Denmark.

\section{REFERENCES}

Álvarez, J. (2016). Meaning making and communication in the multimodal age: Ideas for language teachers. Colomb. Appl.Linguist.J. 18(1), 98-115.

Arola, K., Sheppard, J. \& Ball, C.E. (2014). Writer/Designer: A guide to making multimodal projects. Boston: Bedford /St Martins.

Baškarada, S. (2014). Qualitative Case Study Guidelines. The Qualitative Report, 19(40), 118. Retrieved June 22, 2020 from http://www.nova.edu/ssss/QR/QR19/baskarada24.pdf.

Bidarra, J. \& Rodrigues, P. (2018). Transmedia storytelling as a framework for effective blended learning design. In Ubachs, G. \& Konings, L. The envisioning report for empowering universities, 31-33. Maastricht: EADTUD. Retrieved April 21, 2020 from https://empowernew.eadtu.eu/images/report/The_Envisioning_Report_for_Empoweri ng_Universities_2nd_edition_2018.pdf 
Bowen, T. (2017). Assessing visual literacy: a case study of developing a rubric for identifying and applying criteria to undergraduate student learning. Teaching in Higher Education. 22(6), 705-719. https://doi:10.1080/13562517.2017.1289507

Chan, B.S.K., Churchill, D. \& Chiu, T.K.F. (2017). Digital literacy learning in higher education through digital storytelling approach. Journal of International Education Research. 13(1), 1-16.

Colley, B., Bilics, A., \& Lerch, C. (2012). Reflection: A key component to thinking critically. The Canadian Journal for the Scholarship of Teaching and Learning. 3(1), 1-19. http://dx.doi.org/10.5206/cjsotl-rcacea.2012.1.2

Cope, B., \& Kalantzis, M. (2009). A grammar of multimodality. The International Journal of Learning. 16(2), 361-423.

Darke, P. and Shanks, G. (2002). Case Study Research. In Williamson, K. Research methods for students, academics and professionals: Information management and systems. 111125. (2nd ed.). Centre for Information Studies.

Dingli, A. and Seychell, D. (2015). The new digital natives: Cutting the cord. Heidelberg: Springer.

Fleming, L. (2013). Expanding learning opportunities with transmedia practices: Inanimate Alice as an exemplar. Journal of Media Literacy Education. 5(2), 366-369. Retrieved, April 30, 2020 from https://digitalcommons.uri.edu/jmle/vol5/iss2/2/.

Gambarato, R.R. \& Dabagian, L. (2016). Transmedia dynamics in education: the case of robot heart stories. Educational Media International. 53(4), 229-243.

Herr-Stephenson, B., Alper, M., Reilly, E., \& Jenkins, H. (2013). T is for transmedia: Learning through transmedia play. Journal of Media Literacy Education. 5(2), 366-369. Retrieved April 22, 2020 from https://digitalcommons.uri.edu/jmle/vol5/iss2/2/.

Jewitt, C. (2008). Multimodality and literacy in school classrooms. Review of Research in Education. 32, 241-267. https://doi:10.3102/0091732X07310586.

Jewitt, C., \& Kress, G. (Eds.) (2003). Multimodal literacy. New York: Peter Lang.

Kalogeras, S. (2014). Transmedia storytelling and the new era of media convergence in higher education. Houndmills: Palgrave Macmillan.

Kress, G. \& Van Leeuwen, T. (2002). Colour as a semiotic mode: notes for a grammar of colour. Visual Communication. 1(3), 343-368.

Kress, G., Jewitt, C., Ogborn, J., \& Tsatsarelis, C. (2001). Multimodal teaching and learning. The rhetorics of the science classroom. London: Continuum.

Lee, Y. \& Ertmer, P.A. (2006). Examining the effects of small group discussions and question prompts on vicarious learning outcomes. Journal of Research on Technology in Education. 39(1), 66-80.

Lim, Fei \& Tan, Serene. (2018). Developing multimodal literacy through teaching the critical viewing of films in Singapore. Journal of Adolescent \& Adult Literacy. 62(1), 291300 https://doi.org/10.1002/jaal.882

Nouri, J. (2018) Students' multimodal literacy and design of learning during self-studies in higher education. Tech Know Learn. 24, 683-698. https://doi.org/10.1007/s10758-0189360-5.

Pence, H.E. (2012). Teaching with transmedia. Journal of Educational Technology System. 40(2), 131-140.

Periasamy, M.S, Gruba, P. Subramaniam, G. (2015). A multimodal literary analysis of a television commercial. 3L: The Southeast Asian Journal of English Language Studies. 24(4), 214-232.

Perry, M.S. (2018). 21st century skills through film production in tertiary education: A transformative assessment in a literature and media course. 3L: Language, Linguistics 
and Literature, The Southeast Asian Journal of English Language Studies. 21(3), 51164.

Pratten, R. (2015). Getting started in transmedia storytelling: A practical guide for beginners. (2nd ed.). CreateSpace Independent Publishing Platform.

Rodrigues, P. \& Bidara, J. (2016). Transmedia storytelling as an educational strategy: A prototype for learning English as a second language. International Journal of Creative Interfaces and Computer Graphics. 7(2), 56-67. https://doi: 10.4018/IJCICG.2016070105.

Sánchez-Martínez, J. \& Albaladejo-Ortega, S. (2018). Transmedia storytelling and teaching experience in higher education. International Journal of Contemporary Education. $1(1), 52-63$.

Serafini, F. (2014). Reading the visual: An introduction to teaching multimodal literacy. New York: Teachers College Press.

Shima Yahya (2018, May 20) Hope \& Home by Le'Bien UKM. [Video] YouTube. Retrieved May 4, 2020 from https://www.youtube.com/watch?v=tV5S6Y0D4fc\&t=226s

Suraini Mohd-Ali, Haliza Harun, Normazla Ahmad Mahir, Norhaili Massari, Noor Sazaai Mat Saad \& Simkin, K. (2018). Meeting the demands of the $21^{\text {st }}$ century English language learning through PBL-LcCRAFT. GEMA Online ${ }^{\circledR}$ Journal of Language Studies. 18(2), 255-266.

Tang, Shaofeng. (2016). Digital storytelling approach in a multimedia feature writing course. Journal of Language Teaching and Research. 7(3),572-578.

The New London Group. (2000). A pedagogy of Multiliteracies designing social futures. In B. Cope, B. and Kalantzis, M. (Eds.), Multiliteracies: Literacy Learning and the Design of Social Futures (pp. 9-38). South Yarra: MacMillan.

Toohey, K., D. Dagenais, A. Fodor, L. Hof, O., Nuñez, A. Singh, \& Schulze, L. (2015). "That sounds so cooool": Entanglements of children, digital tools, and literacy practices. TESOL Quarterly. 49(3), 461-485.

Wong, L-H., Chen, W. \& Jan, M. (2012). How artefacts mediate small-group co-creation activities in a mobile - assisted seamless language learning environment? Journal of Computer Assisted Learning. 28(5), 411-424. https://doi.org/10.1111/j.13652729.2011.00445.x

Zammit, K. (2010). The New Learning Environments framework: Scaffolding the development of multiliterate students. Pedagogies: An International Journal. 5(4), 325-337. https://doi:10.1080/1554480X.2010.509479.

\section{ABOUT THE AUTHOR}

Melissa Shamini Perry (PhD) is a Senior Lecturer at the Centre for Research in Languages and Linguistics, The National University of Malaysia. Her research interests are in the area of social semiotics, multimodality, applied literature, media and popular culture narratives and alternative assessments. She has headed a research on the applications of Transmedia and Business storytelling in corporate and higher education contexts in Malaysia. 